\title{
The Effect Addition of Winged Bean and Konjac Flour on the Quality of Instant Cassava-Corn Noodles
}

\author{
Satrijo Saloko*, Siska Cicillia, Siti Rakmah \\ Faculty of Food Technology and Agroindustry, Mataram University, Jl. Majapahit No.62 Mararam 83126, \\ Indonesia
}

*Corresponding author:

E-mail: s_saloko@unram.ac.ic

\begin{abstract}
This study aims to determine the effect of addition winged bean and konjac flour on the quality of instant corn noodles. The experimental design used was a Completely Randomized Design (CRD) with one factor. The factor which is done in the formulation of adding winged bean flour and konjac flour consisting of six treatments. The treatment was $\mathrm{P}$ (presentation of cornflour : mocaf: konjac flour : winged bean flour) included P1 (65\%: 20\%:0\% : 15\%); P2 (65\% : 20\% : 3\% : 12\%); P3 (65\% : 20\% : 6\% : 9\%); P4 (65\% : 20\% :9\% : 6\%); P5 (65\% : 20\% : 12\% : 3\%) and P6 (65\% : 20\% : 15\% : 0\%). The measured parameters of noodle quality are water content, protein content, dietary fiber content, fat content, calcium content, color, cooking time, cooking loss, rehydration, and organoleptic quality including taste, aroma, and texture. The addition of winged bean flour and konjac flour gives a significantly different effect on Moisture content, protein content, dietary fiber content, fat content, Ca content, $\mathrm{Zn}$ content, color, cooking loss, cooking time, rehydration, hedonic aroma, and taste both hedonic and scoring. The best treatment was obtained in the treatment of P3 (9\% winged bean flour: $6 \%$ konjac flour) with a water content of $4.50 \%$; protein content $11.39 \%$; dietary fiber content of $20.01 \%$; fat content $2.74 \%$; Calcium content $0.06 \%$; Zink content 2,84 ppm; L value of 59.59 before brewing and $50.15 \%$ after brewing; ${ }^{\circ}$ hue before brewing 76.11 and after brewing 77.93; cooking time 10.32 minutes; cooking loss $0.66 \%$ and rehydration 10.18 minutes.
\end{abstract}

Keywords: Instant corn noodle, winged bean flour, konjac flour

\section{Introduction}

The 2014 Global Nutrition Report shows that Indonesia is included in 17 countries out of 117 countries that have three nutritional problems i.e stunting, wasting, and overweight in infants. The Toddlers aged 24-59 months are included in the group of people who are susceptible to nutrition, (the group that suffers the most from nutritional disorders) while at present they are experiencing a relatively rapid growth process. Stunting is a cumulative process and was caused by inadequate nutrient intake or recurrent infectious disease or both. Stunting can also occur before birth and is caused by poor nutritional intake during pregnancy, very poor parenting, poor food quality in line with the frequency of infectious diseases that can inhibit growth. Disruption of linear growth or stunting occurs mainly in the first 2 to 3 years of life and is a reflection of the interaction effect between lack of energy intake and nutrient intake. Therefore, the infant needs foods that contain high nutrition and high fiber (Ayuningtyas, Simbolon, \& Rizal, 2018). One of the foods that can be improved in nutrition and are quite attractive to children is noodles.

Noodle is one of the food products that are popular and liked by various groups of people. Noodles can be consumed as an alternative food substitute for rice because its carbohydrate content is quite high, more practical, and cheaper. Noodles can be classified into several types: raw/fresh noodles, wet noodles, dry noodles, and instant noodles. In Indonesia, noodles are the

How to cite:

Saloko S., Cicillia, S., Rakmah, S. (2020). The effect addition of winged bean and konjac flour on the quality of instant cassava-corn noodles. ${ }^{\text {st }}$ International Conference Eco-Innovation in Science, Engineering, and Technology. NST

Proceedings. pages 8-20. doi:10.11594/ nstp.2020.0502 
second staple food after rice, with the most popular type of noodles is instant noodles. Indonesia is the second-largest instant noodle consumer in the world with total consumption in 2012 reaching 14.1 billion packs. In general, noodles are made from wheat flour or wheat so that the increase in noodle consumption in non-wheat-producing countries will cause dependence on wheat imports including Indonesia. Therefore, efforts are needed to reduce the use of wheat flour as a raw material for making noodles. One alternative is to substitute wheat flour with cornflour (Darmajana, Ekafitri, \& Indrianti, 2016).

Corn is a food that has the potential to be processed into non-rice and non-wheat staple food so that it can reduce dependence on rice and wheat. The nutritional content of corn is not inferior to rice or flour. Corn has the advantage of being a functional food with a high content of food fiber, $\mathrm{Fe}$, and beta-carotene (pro-vitamin A) content (Suarni \& Yasin, 2011). Besides, corn is a food that is classified as a moderate glycemic index. Besides having nutritional advantages, corn production in Indonesia is quite high. Corn flour is processed from corn which has different characteristics from wheat flour which is the main ingredient that is commonly used to make noodles. Wheat flour contains gluten which is a complex protein that can give elastic and chewy properties to wheat noodles. This type of protein is not found in corn flour. Therefore, it is necessary to add other types of flour to replace the existing gluten function in the flour so that it can help the formation of a dough that has an elastic texture, compact and easily formed into sheets and printed into noodle strands. The type of flour that can be added to the process of making corn noodles is modified cassava flour (mocaf).

Mocaf is flour from cassava which is processed through the principle of substituting fermented cassava cells. Some advantages possessed by mocaf are the higher dissolved fiber content of cassava flour, higher mineral content than rice and wheat, higher digestibility than cassava tapioca. Mocaf complex carbohydrate content is higher (87.3\%) compared to wheat flour (60-68\%). The mocaf fiber content is also higher (3.4\%) compared to wheat flour (2-2.5\%). According to Salim (2011), lower air content in mocaf (6.9\%) requires a longer shelf life, while lower ash content $(0.4 \%)$ makes mocafs more colorful than wheat flour. In general, instant noodle products on the market have lower nutritional value, such as protein and fiber, ingredients need to be added that can increase the protein content of instant noodles such as winged bean flour. One natural ingredient that contains high protein in Indonesia is the winged bean (Psophocarpus tetragonolobus $\mathrm{L}$ ). Winged bean is a potential natural resource that contains high protein after soybeans, which is about $43 \%$ of protein from its dry weight. Winged bean is a multi-purpose food crop. Almost all parts of winged bean plants, such as leaves, flowers, young pods, tubers, and seeds can be used for food because the nutritional content is quite high. In $100 \mathrm{~g}$ of winged bean seeds, there are $3.7 \mathrm{~g}$ of dietary fiber. Also, winged bean contains important minerals such as calcium, zinc, sodium, potassium, magnesium, phosphorus, and iron (Setyohadi, Permaningthyas, \& Putri, 2016).

Konjac flour is an alternative food ingredient that is low in fat and high in fiber. Konjac flour contains relatively high levels of glucomannan at $64.98 \%$, high fiber content at $2.5 \%$, and low-fat content at $0.02 \%$. Konjac flour is a polysaccharide that contains very low calories which is very good as a source of dietary fiber. According to research Faridah and Widjanarko (2014) states that the addition of konjac flour to the manufacture of mocaf substitution noodles produces a moisture content of $31.77 \%$, crude fiber content of $4.58 \%$. The level of crude fiber is higher compared to control noodles because konjac has high glucomannan content which can be used as a functional food. The purpose of this study is to determine the effect of the addition of wing bean seed and Konjac flour formulations on the nutritional content of instant corn noodles. brands obtained from Madam Shop, garlic, onion, pepper.

The tools used are baking pan, basin, dropper pipette, volume pipette, knife, pan presto maxim type $12 \mathrm{~L}$ Teflon material with a capacity of 12 liters with dimensions of $36 \mathrm{~cm} \times 25 \mathrm{~cm} \times 36 \mathrm{~cm}$ and weight $5.4 \mathrm{~kg}$, basin, gas stove, spilled panic, spoon, kleong, blender, 100 mesh sifter, analytical balance, EXCT-02 SC type extruder machine with a production capacity of $10 \mathrm{~kg} / \mathrm{hour}$ with 63.6 
rpm upper and lower screw rotational speeds and cutting blade speeds up to $270 \mathrm{rpm}$ and an empty weight of $210 \mathrm{~kg}$, plastic gloves, desiccators, masks, $100 \mathrm{ml}$ bubble baths, $250 \mathrm{ml}$ Erlenmeyer, cabinet dryers, porcelain cups, test tubes, small Kjeldahl flasks, large Kjeldahl flasks, distillation machines, and titration devices

\section{Material and Methods}

The materials used are corn obtained from Central Lombok, cassava obtained from SayangSayang Market, Grade B Konjac flour obtained from Brawijaya University, winged bean seeds obtained from Mandalika Market, salt, eggs, CMC, and butterfly baking powder.

This study uses an experimental method carried out in the Laboratory. The design used in this study was a Completely Randomized Design (CRD) with a single factor experiment namely the concentration of winged bean flour and Konjac flour consisting of 6 treatments and 3 replications by setting corn flour concentration of $65 \%$ and mocaf of $20 \%$. Treatment Factor (Corn Flour: Mocaf: Winged Bean Flour: Konjac Flour).

$$
\begin{aligned}
& \text { P1 }=65 \%: 20 \%: 0 \%: 15 \% \\
& \text { P2 }=65 \%: 20 \%: 3 \%: 12 \% \\
& \text { P3 }=65 \%: 20 \%: 6 \%: 9 \% \\
& \text { P4 }=65 \%: 20 \%: 9 \%: 6 \% \\
& \text { P5 }=65 \%: 20 \%: 12 \%: 3 \% \\
& \text { P6 }=65 \%: 20 \%: 15 \%: 0 \%
\end{aligned}
$$

The parameters observed in this study were chemical parameters such as water content, protein content, fat content, fiber content, Calcium content, and Zinc content. Physical parameters including color (the Msez User method Manual), cooking loss, cooking time, and rehydration while for organoleptic parameters (SNI 7622: 2011).

\section{Results and Discussion Water content}

Water content is one of the most important characteristics because it can affect the appearance, texture, taste, and shelf life of food (Winarno, 2008). The effect of the addition of winged flour and Konjac flour formulations on the water content of instant corn noodles can be seen in Figure 1.

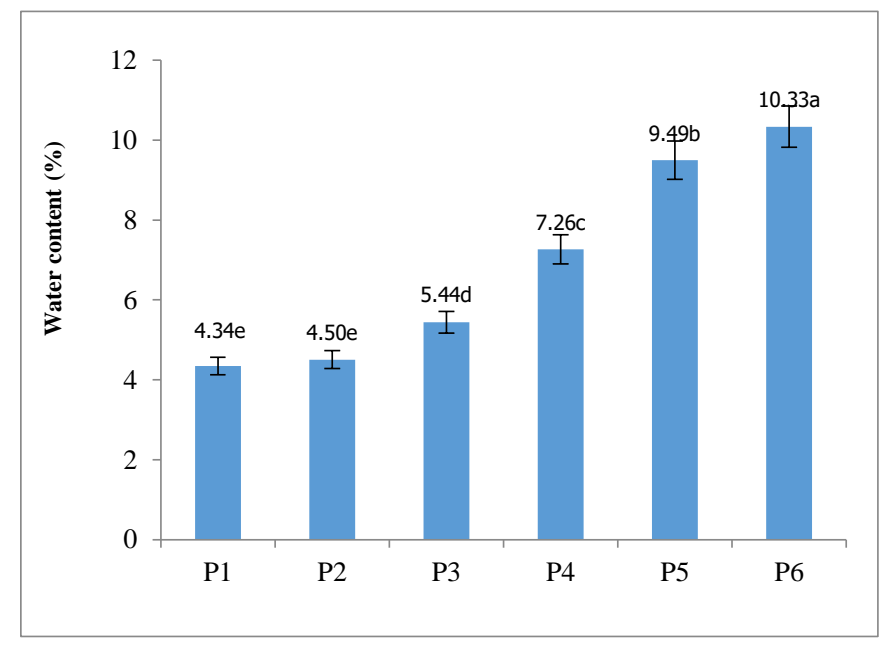

Figure 1. The water content of Instant Cassava-Corn Noodles 
Figure 1. showed that the addition of winged bean and konjac flour with various concentrations affected the water content of instant cassava-corn noodles. The lowest water content was obtained at P1 at $4.34 \%$ and the highest water content was obtained at P6 at $10.33 \%$. This is because the water content of raw winged bean flour is $8.08 \%$ and Konjac flour is $9.67 \%$. The higher the concentration of the addition of Konjac flour, the higher the water content of instant cassavacorn noodles. The results of this study are following research (Panjaitan, 2017) in the manufacture of wet noodles with the substitution of konjac flour producing water content that increases with the increasing proportion of konjac flour. According to (Wen et al., 2008) an increase in water content is caused by konjac flour having glucomannan which can absorb water up to 200 times its weight.

According to the National Standards Agency for SNI 01-3551 (2000), the maximum water content requirement for instant noodles that has been set for instant noodles with a drying process is $14.5 \%$. The results showed that the range of water content of instant corn noodles is $4.34-10.33 \%$ so it can be said to have met SNI.

\section{Protein content}

Protein is needed by every organism and microorganism in its survival. Protein is useful for cell metabolism, tissue formation, and others. The relationship between the addition of winged bean flour and konjac flour can be seen in Figure 2.

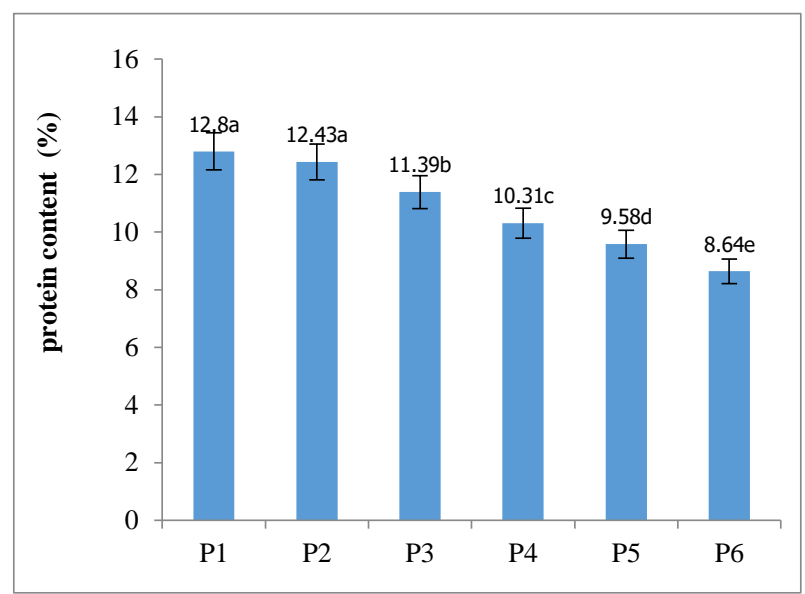

Figure 2. The protein content of instant cassava-corn noodles

Figure 2 showed that the formulation of added winged bean flour and konjac flour influenced the protein content of instant cassava-corn noodles. The highest protein content was in the P1 treatment of $12.80 \%$ and the lowest protein content was in the P6 treatment of $8.64 \%$. This was due to the protein content in the raw material i.e winged bean flour by $33.32 \%$ and konjac flour $2.39 \%$. The higher the concentration of winged bean flour, then the protein content of instant cassava-corn noodles is increasing. This is in line with research conducted by Saputro (2016) on the effect of the use of winged bean seed flour as a substitute for rice flour in making apem (traditional cakes) on protein content and acceptability. The results of his research stated that the protein content in apem cakes has increased with the addition of winged bean flour which is more and more. Based on SNI 01-3551-2000, instant noodles that are not from wheat with a minimum protein content of $4 \%$ and noodles from wheat with a minimum of $8 \%$. The results of the protein content of this study were $8.64 \%$ to $12.80 \%$ so that the protein content of these instant corn noodles had met SNI standards. 


\section{Dietary fiber content}

Dietary fiber is included in the non-starch polysaccharide (NSP) polysaccharide consisting of cellulose and non-cellulose components, both of which are simple sugar polymers (Barasi, 2009). The relationship between the addition of winged bean flour and konjac flour can be seen in Figure 3.

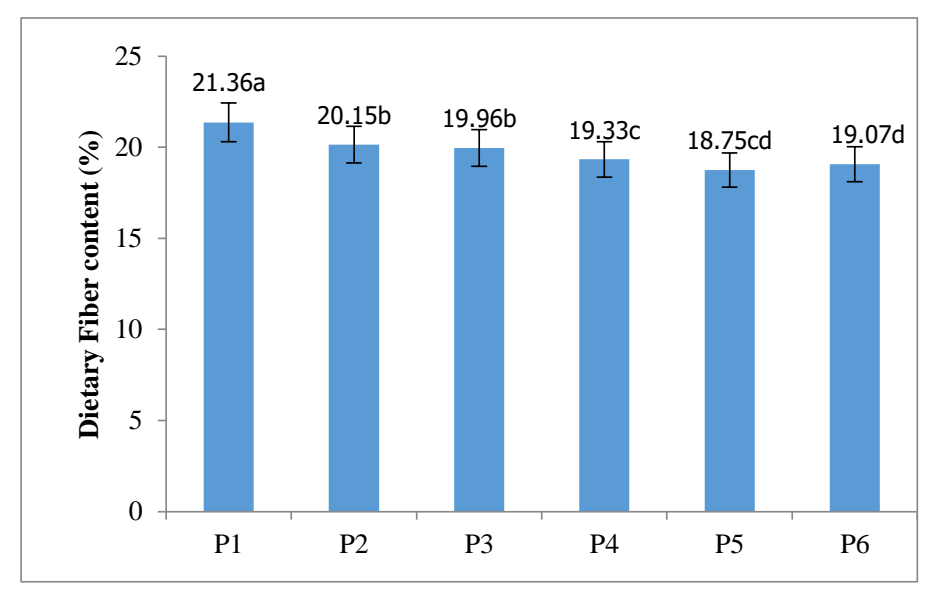

Figure 3. Dietary fiber content of instant cassava- corn noodles

Figure 3. showed that the addition of winged bean flour and konjac flour influenced the food content of instant cassava-corn noodles. The higher the wing bean seed formulation the higher the food dietary fiber content in instant cassava- corn noodles. This is in line with research conducted by Susanti, Wijanarka, \& Nareswara (2018) regarding the determination of the glycemic index and glycemic load on red rice flour cookies and winged bean. The results showed that cookies with the addition of $35 \%$ winged bean flour produced a food fiber content of $13.25 \%$ higher compared to control cookies without the addition of winged bean flour.

\section{Fash content}

Fat is a chemical compound that contains elements $\mathrm{C}, \mathrm{H}$, and $\mathrm{O}$. Fat is one of the nutrients the body needs because of its use to provide energy of $9 \mathrm{Kcal} / \mathrm{g}$. The relationship between the addition of winged bean flour and konjac flour can be seen in Figure 4.

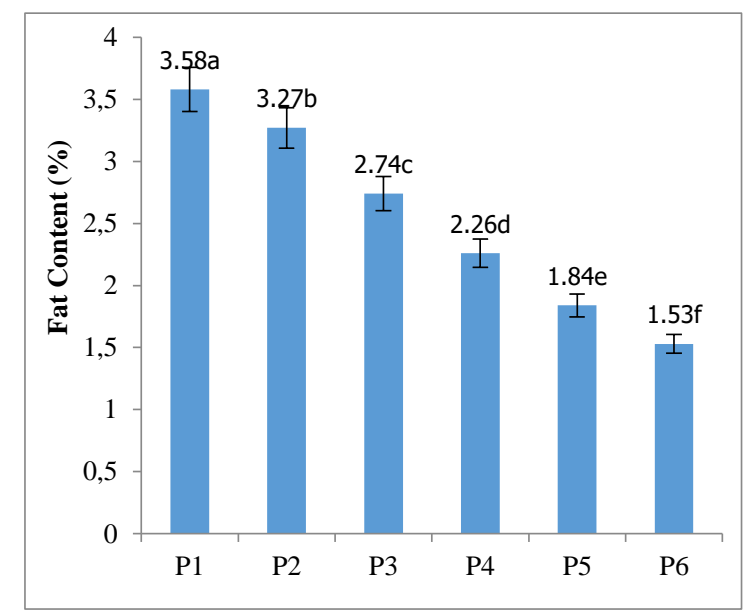

Figure 4. The fat content of Instant Cassava-Corn Noodles 
Figure 4 showed that the formulation of added winged bean flour and konjac flour influenced the fat content of instant cassava-corn noodles. The highest fat content was obtained at P1 treatment at 3.58\% and the lowest fat content was at P6 treatment at $1.53 \%$. The low-fat content in instant cassava-corn noodles is influenced by the fat content of raw materials including konjac flour fat content of $1.12 \%$ and winged fat flour content of $20.35 \%$. The lower the formulation of winged bean flour, the lower the fat content and vice versa, the higher the winged bean powder formulation, the higher the fat content of instant cassava-corn noodles.

The results of this study are in line with research conducted by Kharismayani et al., (2009) on the formulation of zapper flakes made from sweet potato flour and winged bean flour as an innovative fast food meal rich in energy and protein. The results of his study showed that the increase in fat content in zapper flakes along with the addition of winged bean flour was higher. According to the National Academy of Science (1975), winged bean seeds have high-fat content.

\section{Calsium content}

Calcium (Ca) is a mineral that is very important for the human body. One of its functions is to form bones and keep them strong. The relationship of the effect of adding winged bean flour and konjac flour to the content of instant cassava-corn noodle can be seen in Figure 5.

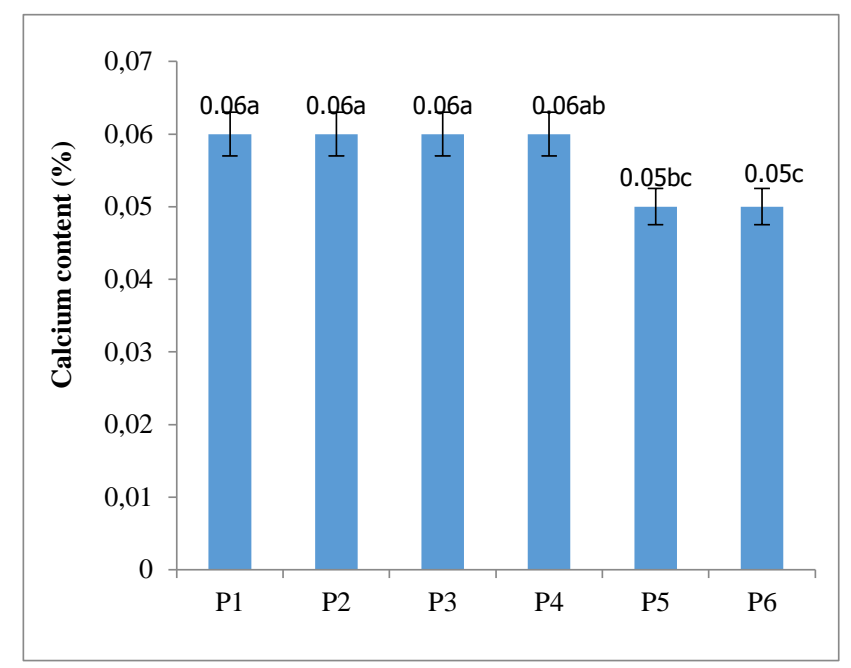

Figure 5. Calcium content of instant cassava-corn noodles

Figure 5. showed that winged bean flour and konjac flour formulations influenced Ca levels of instant cassava- corn noodles. The highest Ca levels were in treatments P1, P2, P3, and P4 at $0.06 \%$ and the lowest at P5 and P6 treatments at $0.05 \%$. This is influenced by the addition of winged bean flour. The less the formulation of adding winged bean flour, the lower the Ca content. This is caused by the raw material used in winged bean flour containing $0.19 \%$ Calcium. Winged bean contains some high minerals. Winged bean has a Ca content of $80 \mathrm{mg} / 100 \mathrm{~g}$ (Ministry of Health Nutrition Directorate of the Republic of Indonesia 1981).

\section{Zinc content}

Zinc is an essential micromineral as a cofactor of more than 100 metalloenzymes that play an important role in cell regeneration, metabolism, growth, and repair of body tissues. The relationship of the addition of winged bean flour and Konjac flour to the Zn content can be seen in Figure 6. 


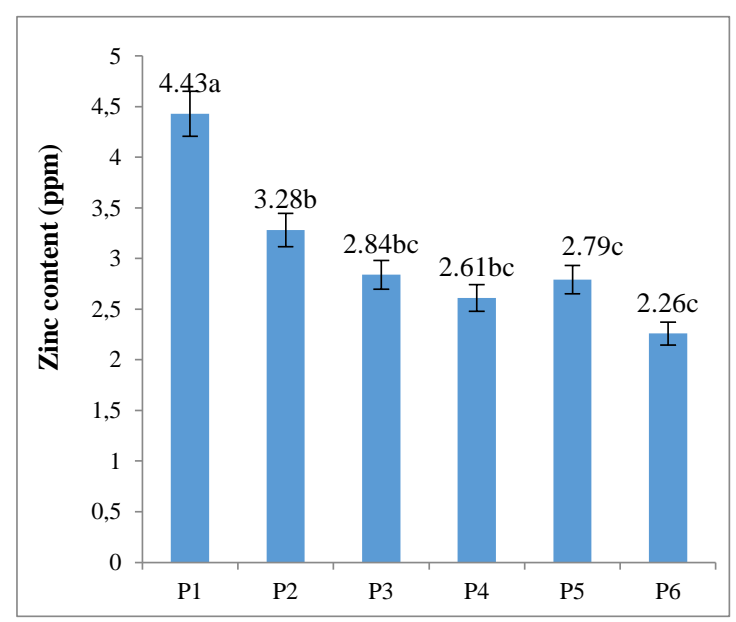

Figure 6. Zink content of instant cassava-corn noodles

Figure 6. showed that the addition of winged bean flour and konjac flour influenced the Zn levels of instant cassava- corn noodles. The highest Zn level was in the P1 treatment at $4.43 \mathrm{pm}$ and the lowest was in the P6 treatment at $2.26 \mathrm{ppm}$. This is influenced by the effect of adding winged bean flour. The lower the wing bean formulation, the less $\mathrm{Zn}$ content, and the higher the formulation of wing bean flour, the higher the $\mathrm{Zn}$ content. This is because winged bean contains important minerals one of which is $\mathrm{Zn}$. In $100 \mathrm{~g}$ winged bean contains 3.1-5 mg Zn.

\section{Lightness value (L)}

Color is one of the important parameters in the assessment of organoleptic tests because the color is the first benchmark for someone in assessing a product, especially in food products. In color testing, the value is calculated using a calorimeter. The $L$ value is the value that states the product brightness parameter and has a value from 0 (black) to 100 (white).

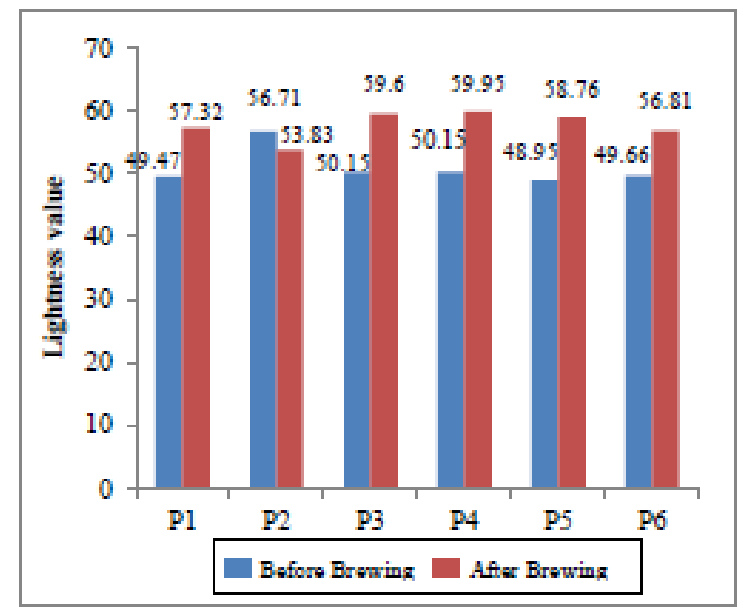

Figure 7. Lightness value of Instant Cassava-Corn Noodles

Figure 7. showed that the addition of winged bean flour and konjac flour affected the value of $\mathrm{L}$ instant cassava- corn noodles. The results showed that the $\mathrm{L}$ value of instant cassava-corn noodles before brewing had a significantly different effect but not significantly different in the value of $L$ brewed noodles. The highest $L$ value in instant cassava-corn noodles before brewing was in the P2 treatment which was 56.71 and the lowest in the P1 treatment was 49.47. The value of L or the brightness of instant cassava-corn noodles increased at P2 treatment but dropped to P5 
and increased again at P6 but not significantly different. This means that the higher the addition of konjac flour, the L value decreases. This is caused by the color of the cream-colored brown colored konjac, making the color of the noodles dark.

\section{${ }^{\circ}$ Hue Value}

The ${ }^{\circ}$ Hue value is a characteristic based on reflected light size ranging from levels 0 to 359. At level 0 is the color of the object, seen in red, 60 is yellow, for green at level 120, while at 180 is cyan.For level 240 is blue and 300 is magenta. The relationship between the addition of winged bean flour and konjac flour to the ${ }^{\circ} \mathrm{Hue}$ value can be seen in Figure 8.

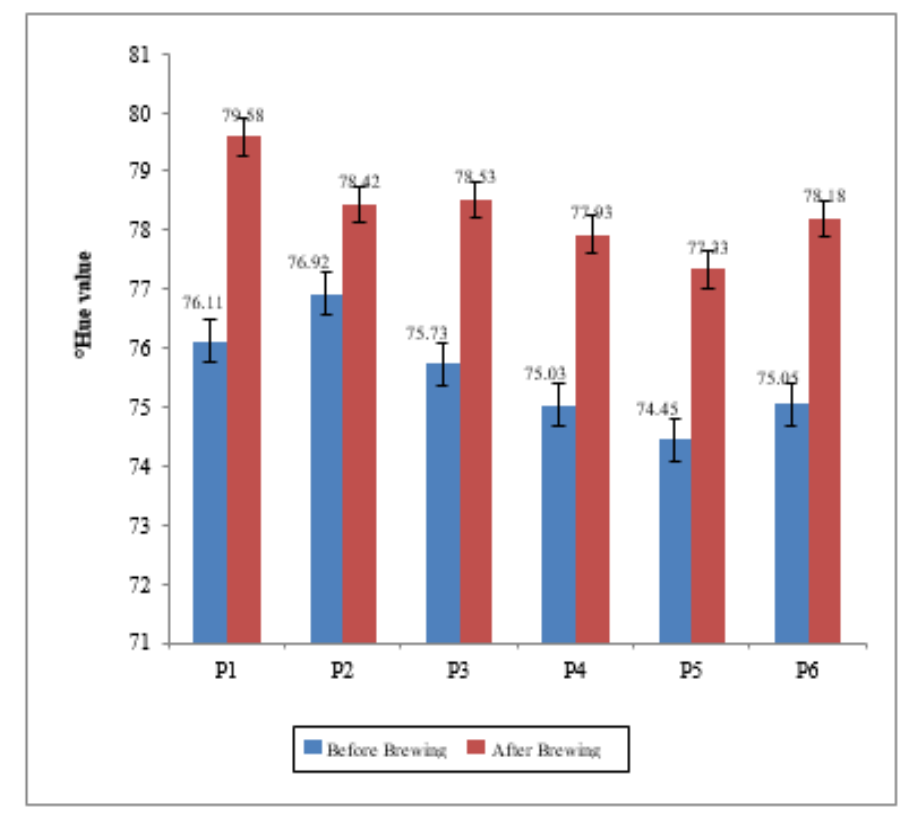

Figure $8 .^{\circ}$ Hue value of Instant Cassava-Corn Noodles

Figure 8. showed that the addition of winged bean flour and konjac flour affected the ${ }^{\circ} \mathrm{Hue}$ of instant cassava-corn noodles. The results showed that the value of ${ }^{\circ} \mathrm{Hue}$ instant cassava-corn noodles value ranged from 74.45 to 76.92 for unbrewed noodles while noodles that had been brewed ranged from 77.33 to 79.58 so that the range of color produced was yellow-red. The results show that the ${ }^{\circ} \mathrm{Hue}$ of instant cassava-corn noodles decreases along with the high addition of konjac flour although it is not too significant. This is because the konjac flour is rather brown. The formulation of raw materials used cornflour which has a yellow pigment so that the color of instant cassava-corn noodles is predominantly yellow.

\section{Cooking loss}

Cooking loss is one of the important factors that influence the quality of cooking noodles. The effect of the addition of winged bean flour and konjac flour can be seen in Figure 9. Figure 9. showed that the addition of winged bean flour and konjac flour influenced the cooking loss of instant cassava-corn noodles. The highest cooking loss value was in the P1 treatment of 1.44 and the lowest was in the P5 and P6 treatments of 0.06 . The cooking loss of instant cassava-corn noodles decreased with an increasing number of konjac flour. This is because konjac flour has a function as a developer, thickener and can bind water so that water molecules are trapped in the gel structure formed by the addition of konjac flour formulation. The maximum cooking loss limit is $8 \%$ according to Collins and Pangloli (1997) so that the value of a cooking loss on instant cassavacorn noodles is acceptable. 


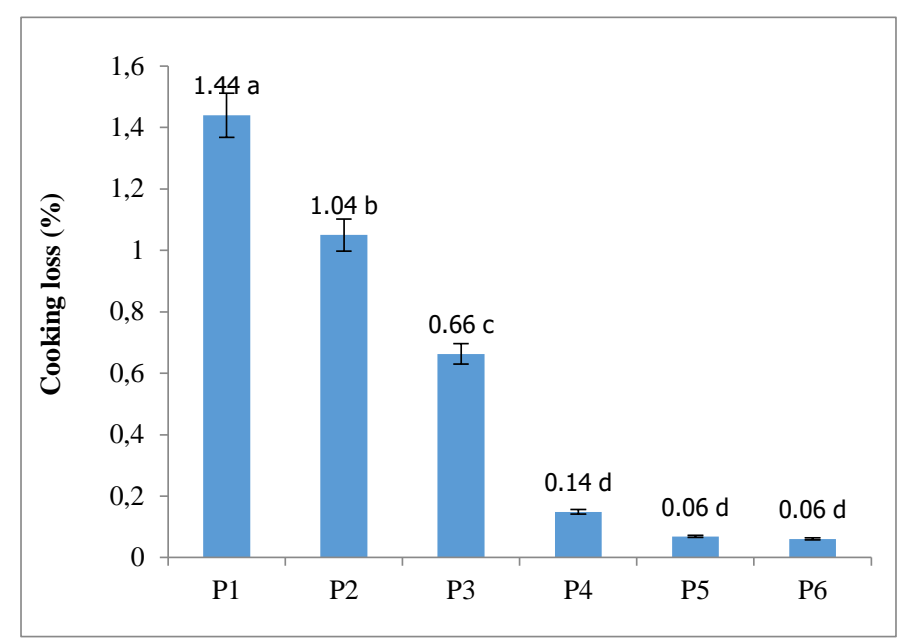

Figure 9. Cooking loss of instant cassava-corn noodles

\section{Cooking time}

Cooking time is the time needed to cook or ripen instant noodles. Cooking time is a parameter that determines the quality of instant noodles. The effect of the addition of winged bean flour and konjac flour can be seen in Figure 10.

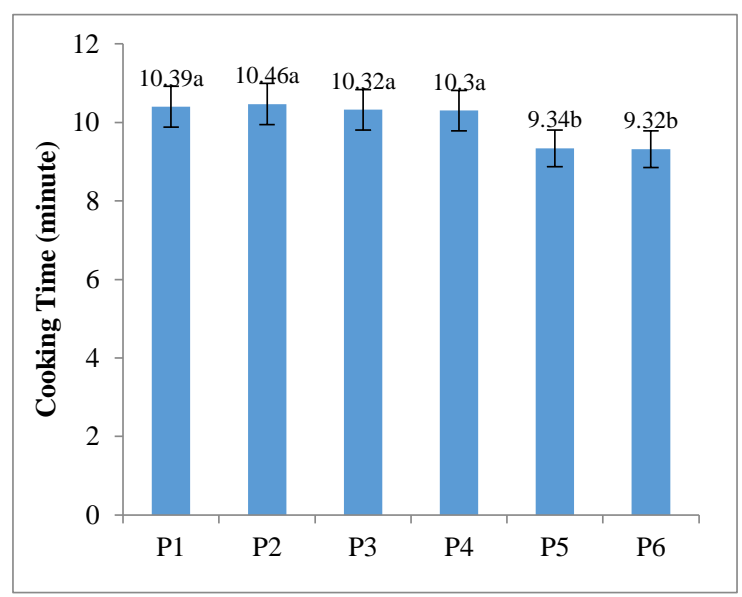

Figure 10. Cooking time of instant cassava-corn noodles

Based on Figure 10. shows that the addition of winged bean flour and konjac flour influences the cooking time of instant cassava-corn noodles. The highest cooking time was in the P1 treatment for 10.39 minutes and the lowest in the P6 treatment for 9.32 minutes. This is due to the addition of konjac flour. The higher the addition of konjac flour, the cooking time will decrease. The temperature and duration of gelatinization depend on the water content and the amount of Purified Konjac Glucomannan (PKG) (Faridah, 2014). Konjac flour used in the raw material for instant cassava-corn noodles contains quite high glucomannan at $57.54 \%$. Konjac flour has a higher gelatinization ability compared to other flour. This is also due to the addition of water which can trigger and accelerate the process of gelatinization of noodles.

\section{Rehydration}

Rehydration or water absorption is the ability of noodles to absorb water maximally. Rehydration time is the time it takes the material to re-absorb water so that a homogeneous texture is 
obtained. The relationship of the effect of addition winged bean flour and konjac flour to the rehydration time instant cassava-corn noodles can be seen in Figure 11.

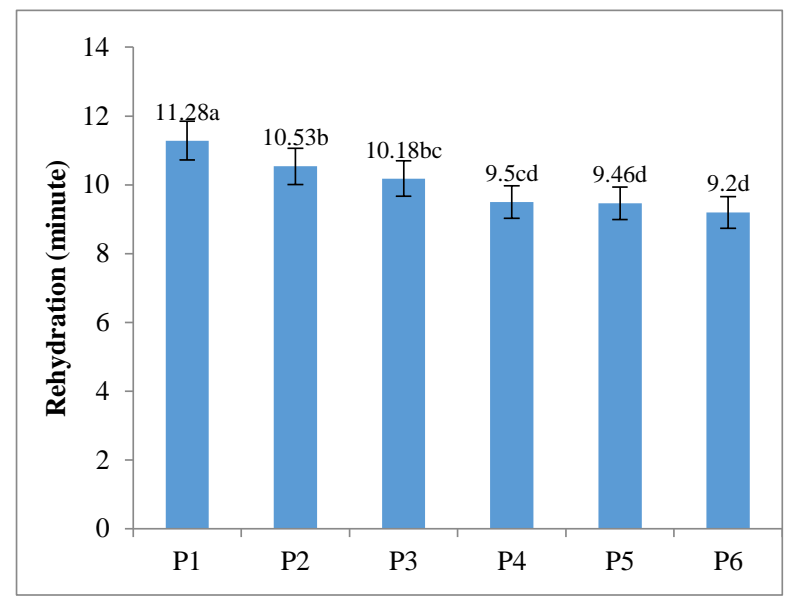

Figure 11. Rehydration of instant cassava-corn noodles

Based on Figure 11 shows that the addition of wing bean and konjac flour significantly affected the rehydration time of instant cassava-corn noodles. The highest rehydration time was at P1 treatment, which was 11.28 minutes and the lowest rehydration time was at P6 treatment, which was 9.2 minutes. This is caused by the raw material used for konjac flour. The higher the addition of konjac flour, the lower the rehydration time. This is due to the water absorption capacity of konjac flour.

Based on research conducted by Faridah and Widjanarko (2014) about the addition of konjac flour to making noodles with substituted mocaf flour, the water absorption capacity of noodles is getting higher. The high absorption of water along with the high addition of konjac flour is due to konjac flour which is easy to absorb water. The high water absorption or rehydration power causes the rehydration time to be shorter. This is also due to Konjac flour having a high glucomannan content.

Taste

Taste is the main factor that determines the taste of food. Taste is a sensory experience produced by stimuli from receptors on the tongue, palate, pharynx, larynx, and other areas around the mouth (Taub \& Singh, 1998). The effect of the addition of winged bean flour and konjac flour can be seen in Figure 12.

Based on Figure 12 shows an approved addition of winged bean flour and konjac flour on the taste of instant cassava-corn noodles. In the panelist hedonic test the average level of panelist preference on the taste of instant corn noodles 2.8-3.55 consists of dislike to dislike. The panelist preference level has decreased from the P1 to P4 settings but the P1 to P4 settings have no real preference. At level P5 the panel preference level increases and decreases at P6 but has no noticeable difference. The taste of instant cassava-corn noodles on average is not liked by panelists because of the influence of winged flour.

To test the scoring, the average taste of instant corn noodles from 3.05 to 4.15 tastes slightly winged to slightly tasteless. The stronger the taste of winged bean flour on panelist noodles the more it doesn't like. The research on the use of cassava flour and winged bean flour as a substitute for flour in making cookies resulting in higher floured panelists rather than dislike the taste of cookies. This is because winged bean flour contains beany flavor after taste. Beany flavor is a distinctive taste of beans. 


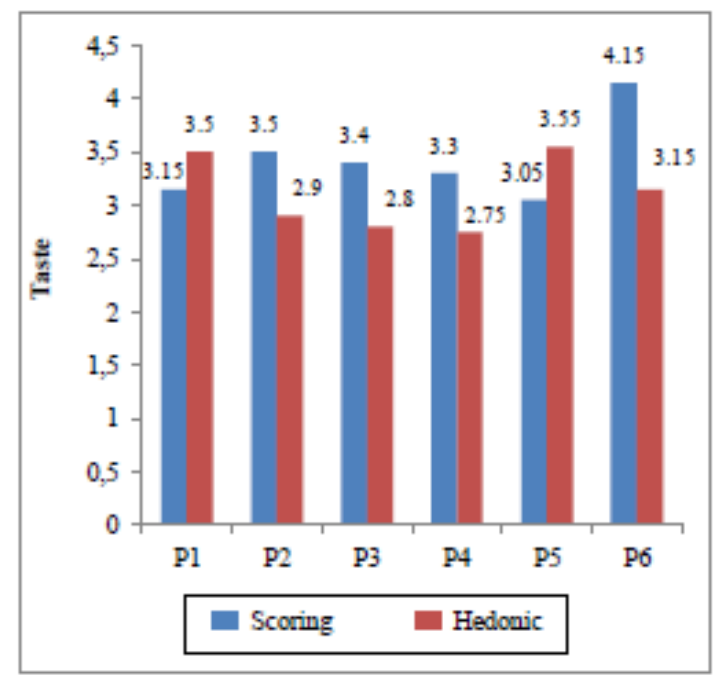

Figure 12. taste of instant cassava-corn noodles

\section{Aroma}

The aroma is one of the parameters in determining the quality of food. The aroma is som thing that can be observed with the sense of smell. To be able to produce aroma, substances must be able to evaporate slightly soluble in water and slightly soluble in fat (Kartika \& Supartono, 1998). The relationship between the influence of the addition of winged bean flour and konjac flour can be seen in Figure 13.

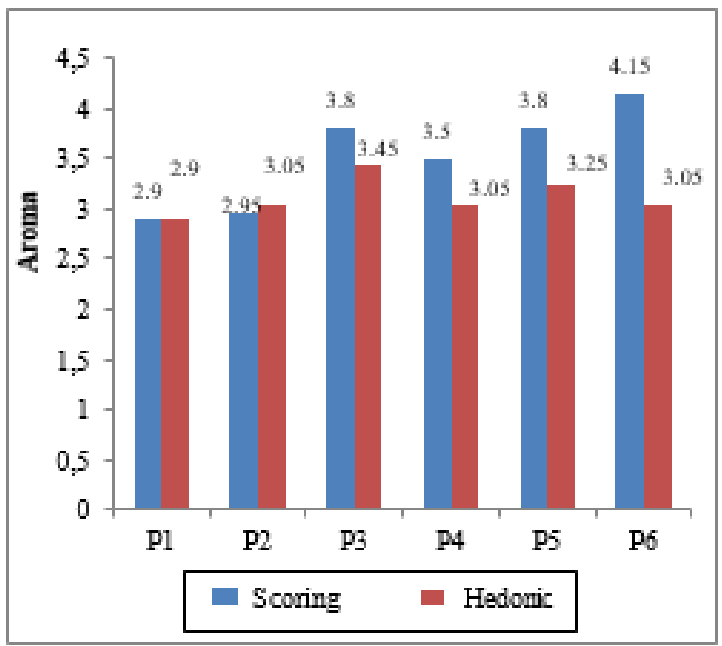

Figure 13. The aroma of instant cassava-corn noodles

Based on Figure 13, the wing bean seed flour and konjac flour influences the aroma of instant cassava-corn noodles. The panelist's preference level for the aroma parameters ranged from 2.9 to 3.45, i.e. dislike to somewhat dislike. This is due to the higher addition of winged bean flour, the panelists increasingly dislike the aroma of instant cassava-corn noodles. The highest value was in treatment P6 which was 4.15 and the lowest value in treatment P1 was 2.9. The more formulations of adding winged bean flour to each treatment, the stronger the aroma of winged bean flour on instant cassava-corn noodles, and panelists do not like it. The low level of panelists' preference for 
the aroma of instant corn noodles is in line with the research of Setiadarma (2001), which shows that milk porridge added with winged bean flour is not liked by panelists as more and more added winged bean flour. This is because the winged beans can produce unpleasant odors caused by the activity of the lipoxygenase enzyme that is naturally present in nuts.

\section{Texture}

The instant noodle texture is one of the factors that determine the quality of instant noodles. The more chewy the noodles produced the better the quality of instant noodles. The relationship between the influence of the addition of winged bean flour and konjac flour can be seen in Figure 14.

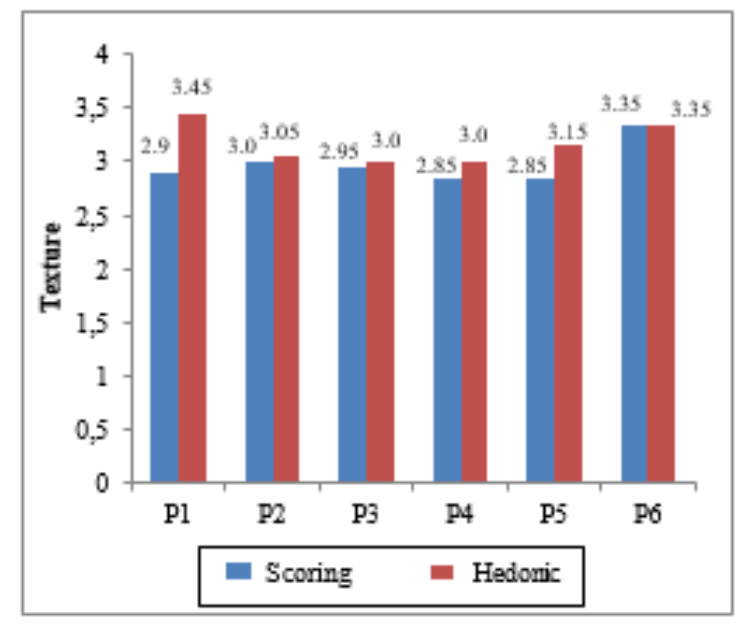

Figure 14. The texture of instant cassava-corn noodles

Based on Figure 14, the level of preference of panelists on the texture parameters of instant cassava-corn noodles ranged from 3.05 to 3.45 which is rather disliked. the level of panelist preference on the texture of instant cassava-corn noodles. For the scoring test ranged from 2.9 to 3.35, which is from not springy to slightly springy. The highest value was found in treatment P6 and the lowest value in treatment P1 was not rubbery. The higher the formulation of added winged bean flour and the less amount of konjac flour, the texture of instant cassava-corn noodles the less chewy. The higher the addition of konjac flour, the higher the level of suppleness. This is because konjac flour contains glucomannan.

\section{Conclusion}

The addition of winged bean flour and konjac flour have a significantly different effect on water content, protein content, dietary fiber content, fat content, Ca content, color, cooking loss, cooking time, rehydration, and aroma scoring, and hedonic taste and taste. scoring. The higher the formulation of winged bean flour, the protein content, dietary fiber content, fat content and Ca content increase, while the water content is lower. The higher the addition of konjac flour, the L value, ${ }^{\circ} \mathrm{Hue}$, cooking loss, cooking time, rehydration is lower. The higher the formulation of winged bean flour, the organoleptic quality of instant cassava-corn noodles tends to decrease. The best treatment was obtained in the treatment of P3 (9\% winged bean flour: $6 \%$ konjac flour) with a moisture content of $4.50 \%$; protein content $11.39 \%$; dietary fiber content $20.01 \%$; fat content $2.74 \%$; Ca level of $0.06 \%$; L value 59.59 before brewing and $50.15 \%$ after brewing; ${ }^{\circ}$ Hue before brewing 76.11 and after brewing 77.93; cooking time 10.32 minutes,cookingloss $0.66 \%$ and rehydration 10.18 minutes. 


\section{Acknowledgment}

We gratefully acknowledge to Ministry of Research Technology and Higher Education of the Republic of Indonesia for "Program Penelitian Teknologi Industri Tahun 2019" funding and the Faculty of Food Technology and Agroindustry, the University of Mataram for the technical support.

\section{References}

Ayuningtyas., Simbolon, D., \& A, Rizal. (2018). Micro nutrient intake for stunting in toddlers. Journal of Health, 9(3), 444449.

Barasi, M. E. (2009). At a glance: Nutrition. Erlangga Jakarta.

Collins, J.L., \& P.Pangloli. (1997). Chemical, physical and sensosry atributs of noodle with added sweetpotato and soy flour. J.of Food Science, 62 (3), 622-625.

Darmajana, D.A., Ekafitri, R., \& Indrianti, N. (2016). Effect of variable size of corn flour parties on the physical characteristics of instant corn noodles. Journal of Food, 5 (1), 1-11.

Faridah, A., \& Widjanarko, S. B. (2014). Adding porang flour to noodle making with MOCAF flour substitution (modified cassava flour). Journal of Food Technology and Industry, 25 (1), 98-105.

Kartika, B.P., \& W. Supartono. (1998). Guidelines for the test of food sensory food. Yogyakarta: Gajah Mada University Press.

Kharismayani, I., et al. (2009). Formulation of zapeer flakes made from sweet potato flour and winged flour as innovations for fast food rich in protein energy. Bogor: PKM Research. Bogor Agricultural Institute.

National Academy of Science. (1975). The winged bean: A hight protein crop for the tropics. Nat, Ac. Of Sci, Washington D.C

Panjaitan, T.W.S., Rosida, D. A., \& Widodo, R. (2017). The quality aspect and the level of consumer preference for wet noodle products with porang flour substitution. Journal of Industrial Engineering HEURISTIC, 14(1), 1-16.

Setiadarma, A.N. (2001). Studying how to make winged flour (Psophocarpus tetragonolobus) as a substitution material in the manufacture of milk porridge products. Thesis. Faculty of Agriculture Bogor Agricultural University. Bogor.

Suarni \& Yasin, M. (2011). Corn as a functional food source. Journal of Food Crop Science and Technology, 6(1), 41-56

Salim, A. (2011). Processing cassava flour into mocaf flour. Yogyakarta: Lily Publisher.

Saputro, D. (2016). Effect of the use of winged bean flour (Psophocarpus tetragonolobus L.) as rice flour substitution in the making of apem cake for protein content and acceptability. Scientific Publications. Faculty of Health Sciences,

Muhammadiyah University. Surakarta.

Setyohadi., Permaningthyas, K., \& Putri, A. (2016). Effects of Winged Seed Flour Substitution (Psophocarpus tetragonolobus L.) in food on protein levels of wistar white mouse serum protein given low-protein diet. FKUB Health Magazine, 3(2), 86-92.

Susanti, A., Wijanarka, A., \& Nareswara, U. S. (2018). Determination of the glycemic index and glycemic load in cookies of red rice flour (Oryza Nivara) and winged beans (Psophocarpus Tetragonolobus L.). Indonesian Nutrition Journal, 2 (1), 69-78.

Taub, T.A., \& Singh, R. P. (1998). Food storage stability. USA: CRC Press.

Wen, X., Wang, T., Wang, Z., Li, L., \& Zhao, C. (2008). Preparation of Konjac Glucomanan Hydrogels as DNA- controlled release International matrix. Int J Biol Macromol, 42 (3), 256-263. https://doi.org:10.1016/j.ijbiomac.2 007.11.006. (Accessed March 8,2020).

Winarno, F.G. (2008). Food and nutrition chemistry. Jakarta: Gramedia Main Library. Jakarta 